Zeszyty Naukowe Szkoły Głównej Gospodarstwa Wiejskiego w Warszawie

Problemy Rolnictwa Światowego tom 18 (XXXIII), zeszyt 2, 2018: 20-32

DOI: $10.22630 /$ PRS.2018.18.2.31

Malgorzata Błażejowska $^{1}$, Waldemar Gostomezyk ${ }^{2}$

Politechnika Koszalińska

\title{
Warunki tworzenia i stan rozwoju spółdzielni i klastrów energetycznych w Polsce na tle doświadczeń niemieckich
}

\section{Conditions for the Creation and State of Development of Cooperatives and Energy Clusters in Poland Compared with Germany}

\begin{abstract}
Synopsis. W polityce energetycznej wykorzystywane są różne formy organizacyjne. Na szczeblu lokalnym i regionalnym doskonale sprawdzają się spółdzielnie energetyczne i klastry energii. Ich główne zalety to: uspołecznienie procesu wytwórczego, łączenie celów społecznych i ekonomicznych oraz korzystny wpływ na poprawę stanu środowiska naturalnego. Celem artykułu było rozpoznanie warunków i stanu rozwoju spółdzielni energetycznych i klastrów energii w Polsce i ich wpływu na rozwój lokalny oraz całego sektora energetycznego na tle doświadczeń niemieckich. W Niemczech funkcjonuje najwięcej spółdzielni energetycznych w Unii Europejskiej. Prowadza one do rozwoju na szeroką skalę energetyki obywatelskiej, w której integrują się interesy wytwórców i konsumentów energii. Przeprowadzona analiza pozwoliła wywnioskować, że spółdzielnie energetyczne powinny mieć elastyczne struktury wynikające z lokalnych potrzeb i możliwości, zaczynając od spółdzielni socjalnych do struktur funkcjonujących w formie klastrów o zasięgu regionalnym.
\end{abstract}

Słowa kluczowe: spółdzielnie energetyczne, klastry energii, energia odnawialna, rozwój lokalny

\begin{abstract}
In energy policy, various organizational forms are used. At local and regional levels, energy cooperatives and energy clusters are perfect. Their main advantages are: socialization of the production process, combining social and economic goals and a beneficial effect on the improvement of the natural environment. The aim of the article was to recognize the conditions and state of development of energy cooperatives and energy clusters in Poland and their impact on local development and the entire energy sector as compared with similar activities in Germany. Germany has the largest number of energy cooperatives that operate in the European Union. They lead to the development of civic energy in which the interests of energy producers and consumers are integrated on a large scale. The conducted analysis led to the conclusion that energy cooperatives should have flexible structures resulting from local needs and possibilities, starting from social cooperatives to structures functioning in the form of regional clusters
\end{abstract}

Key words: energy co-operatives, energy clusters, renewable energy, local development

JEL Classification: Q42, Q56, R11

\footnotetext{
${ }^{1}$ dr; Wydział Nauk Ekonomicznych Politechniki Koszalińskiej, ul. Kwiatkowskiego 6E, 75-343 Koszalin, e-mail: blazejowska@op.pl; https://orcid.org/0000-0002-3279-9879

${ }^{2}$ dr inż.; Wydział Nauk Ekonomicznych Politechniki Koszalińskiej, ul. Kwiatkowskiego 6E, 75-343 Koszalin, e-mail: waldemar.gostomczyk@tu.koszalin.pl; https://orcid.org/0000-0003-1357-7493
} 


\section{Wprowadzenie}

Dotychczasowe systemy energetyczne krajów wysoko uprzemysłowionych charakteryzowały się wysoce scentralizowanym wytwarzaniem energii (głównie na bazie paliw kopalnych), czego skutkiem były znaczne szkody ekologiczne. W latach dziewięćdziesiątych XX wieku w reakcji na te skutki zorganizowane grupy społeczne zaczęły tworzyć spółdzielnie energetyczne, jako odpowiedź na globalne problemy środowiskowe i zapewnienie oddolnych, zbiorowych rozwiązań dla zaspokojenia lokalnych potrzeb. W ten sposób spółdzielnie energetyczne i społeczności lokalne odgrywają coraz większą rolę $\mathrm{W}$ przyśpieszaniu przejścia w kierunku zrównoważonego sektora energetycznego (Tarhan, 2015).

Doświadczenia wielu krajów europejskich wskazują, że w polityce energetycznej można wykorzystywać nowe formy organizacyjne, które dotychczas doskonale sprawdzały się w realizacji usług społecznych. Formą tą mogą być spółdzielnie energetyczne jako jedna z form prawnych przedsiębiorstw społecznych. Struktury te powinny otrzymać szczególne preferencje na obszarach wiejskich, gdzie w porównaniu do obszarów miejskich poziom bezrobocia, ubóstwa i zagrożenia ubóstwem jest znacznie wyższy. Problem wykluczenia społecznego i energetycznego nabiera szczególnego wyrazu, zwłaszcza na terenach popegeerowskich, problemowych, na których ludność uległa marginalizacji. Według raportu IBS (2018) problem zaspokojenia podstawowych potrzeb energetycznych ma obecnie $12,2 \%$ populacji Polski. Z tego badania - na podstawie danych z 2016 r. wynika, że taka sytuacja w większości dotyczy mieszkańców wsi. Stopa ubóstwa energetycznego sięga w tej grupie 20\% i dotyczy zwłaszcza mieszkańców starych, bez termomodernizacji domów jednorodzinnych.

Pomimo podejmowanych przez różne instytucje i organizacje prób zmiany takiego stanu rzeczy, nie udało się znaleźć rozwiązania tego problemu. Ta grupa pozbawionych pracy mieszkańców wsi charakteryzuje się specyficzną świadomością i postawą wobec otaczającej rzeczywistości. Ogranicza to ich możliwości ekonomiczne i zmniejsza szansę na rynku zawodowym. Na tych terenach cele społeczne powinny być traktowane równoważnie z celami ekonomicznymi. Obecnie najprostszą i pożądaną formą aktywizacji tej grupy społecznej powinno być tworzenie socjalnych spółdzielni energetycznych zajmujących się pozyskaniem, przetwarzaniem biomasy a docelowo również energii. Rozwój wsi wymaga znacznej poprawy jakości zaopatrzenia w energię. Najlepszym rozwiązaniem wydaje się rozwój rozproszonych źródeł energii na obszarach słabo zurbanizowanych, wykorzystujących lokalne, odnawialne zasoby. Pierwotnym źródłem energii dla ludzkości była biomasa. Na obszarach wiejskich istnieją jej znaczne ilości, które przy niewielkim nakładzie można efektywnie zagospodarować. Znaczenie wykorzystania OZE, zwłaszcza biomasy przyczynia się do rozwoju lokalnego, zwłaszcza rozwoju rynku pracy (Gradziuk, 2017). Ten kierunek rozwoju bardzo dobrze odzwierciedlają poglądy Ernsta Schumachera (1981), który pisał: "miejsca pracy trzeba tworzyć na obszarach, gdzie dziś właśnie żyją ludzie, a nie w miastach do których emigrują; stosowane metody wytwarzania powinny być proste, by minimalizować popyt na wysokie kwalifikacje, i to nie tylko $\mathrm{w}$ bezpośredniej produkcji, ale i w sferze podaży surowcowej, w systemie organizacyjnym, finansowaniu, marketingu; towary należy produkować głównie z surowców lokalnych i na potrzeby rynków lokalnych".

Z ustawy Prawo energetyczne (Dz.U. z 2005, Nr 62, poz.552 z późn.zm.) wynika, że na gminach spoczywa obowiązek planowania i zaopatrzenia energetycznego, którego 
realizacja nieść może za sobą takie korzyści jak: zapewnienie trwałości i niezawodności dostawy wymaganych ilości energii, rozwój gospodarczy regionu, racjonalne wykorzystanie lokalnych zasobów energii oraz tworzenie miejsc pracy $\mathrm{w}$ obrębie wspólnoty samorządowej. W znowelizowanej 22 czerwca $2016 \mathrm{r}$. ustawie o odnawialnych źródłach energii (OZE) (Dz.U. z 2015, poz. 478 z późn.zm.) wprowadzono definicje lokalnych struktur energetycznych - spółdzielni energetycznych i klastrów energii. Z treści art. 2 pkt.33 a tego aktu prawnego wynika, że spółdzielnia energetyczna jest zrzeszeniem, które ma na celu produkcję energii na użytek własny członków zlokalizowanych na terenie gminy wiejskiej lub miejsko-wiejskiej. Sumaryczna produkcja energii limitowana jest W zależności od nośnika - energia elektryczna (moc jednostek do $10 \mathrm{MW}$ ), biogaz (wydajność do $40 \mathrm{mln} \mathrm{m} 3$ rocznie) oraz ciepło (moc cieplna do $30 \mathrm{MWt}$ ). Zgodnie $\mathrm{z}$ definicją zawartą $\mathrm{w}$ art. 2 pkt.15a ustawy o OZE, klaster energii to cywilnoprawne porozumienie, w skład którego mogą wchodzić osoby fizyczne, osoby prawne, jednostki oraz instytuty badawcze lub jednostki samorządu terytorialnego, dotyczące wytwarzania i obrotu energią z OZE.

Celem artykułu było rozpoznanie warunków i stanu rozwoju spółdzielni energetycznych i klastrów energii w Polsce i ich wpływu na rozwój lokalny oraz całego sektora energetycznego na tle doświadczeń niemieckich, które stanowią idealny wzorzec dla pozostałych krajów w tej dziedzinie.

Materiałem badawczym były dokumenty przedstawiające zmiany prawne (w szczególności kolejne nowelizacje ustawy o odnawialnych źródłach energii), dane statystyczne, raporty oraz doświadczenia państw europejskich (głównie Niemiec) oraz studium przypadku tworzenia klastra energetycznego w północnej części Polski. Metody badawcze wykorzystane $\mathrm{w}$ pracy to przede wszystkim analizy danych statystycznych pokazujących tendencje we wzroście spółdzielni energetycznych w krajach UE, raporty, opracowania GUS-u oraz literatury krajowej i zagranicznej. Analizy te pozwolity sformułować wnioski określające stan rozwoju spółdzielni energetycznych w polskich realiach prawnych i gospodarczych.

\section{Spółdzielnie energetyczne w Niemczech}

Spółdzielnie energetyczne to bardzo powszechna praktyka w Niemczech, Danii, Austrii, Szwecji i Holandii. W ostatnich latach zajmują one pierwsze miejsce wśród nowo tworzonych spółdzielni. Wytyczne za pomocą których realizują swoje wartości to (Cooperative Energy, 2004):

1. Dobrowolne i otwarte członkostwo - spółdzielnie są organizacjami wolontariackimi, dostępnymi dla wszystkich osób mogących korzystać z ich usług i gotowi zaakceptować obowiązki członkostwa.

2. Demokratyczna kontrola członków - spółdzielnie to organizacje demokratyczne kontrolowane przez swoich członków, którzy aktywnie działają w ustalaniu zasad i podejmowaniu decyzji.

3. Autonomia i niezależność - spółdzielnie są autonomicznymi, samopomocowymi organizacjami kontrolowanymi przez swoich członków.

4. Edukacja, szkolenia i informacje - spółdzielnie zapewniają edukacje i szkolenia dla swoich członków, wybranych przedstawicieli, menedżerów i pracowników, aby mogli skutecznie przyczyniać się do rozwoju spółdzielni. 
5. Troska o społeczność - spółdzielnie pracują na rzecz zrównoważonego rozwoju swoich społeczności poprzez zasady zatwierdzone przez ich członków.

Zgodnie z danymi europejskiej organizacji REScoop zrzeszającej kooperatywy energetyczne i grupy obywatelskie (rys. 1) najwięcej spółdzielni energetycznych w 2014 roku było w Niemczech - 942, Danii - 657 i Austrii - 390.

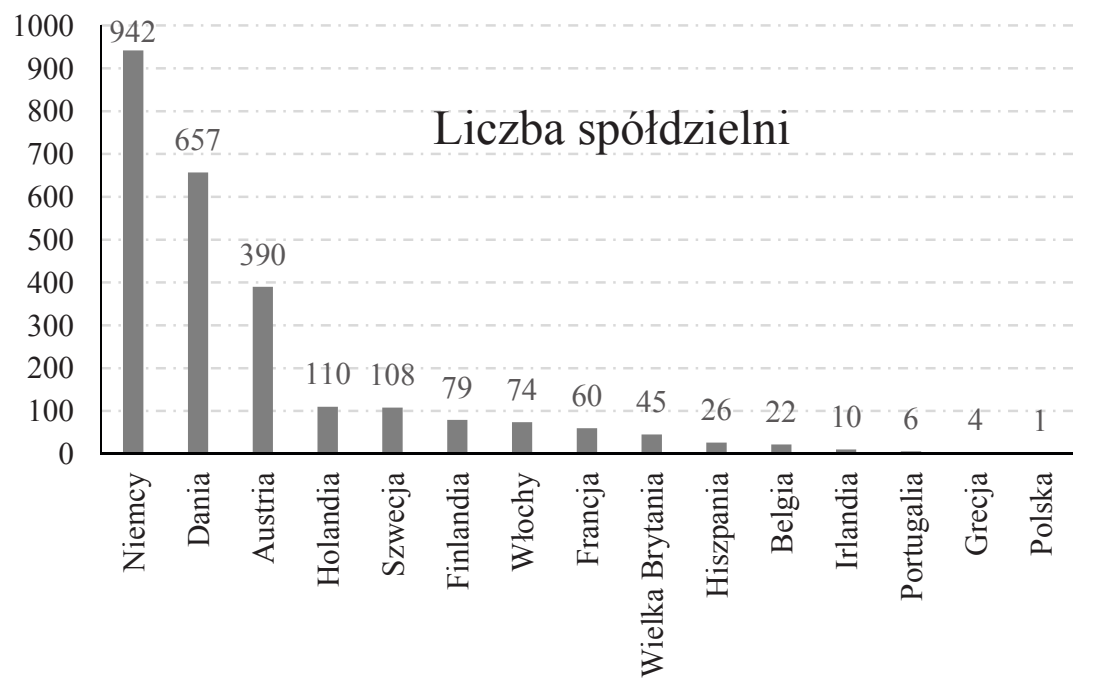

Rys. 1. Spółdzielnie energetyczne w UE w 2014 roku

Fig. 1. Energy cooperatives in the UE in 2014

Źródło: opracowanie na podstawie: Odmienić przyszłość energetyki..., 2015.

W krajach tych spółdzielczość ma wieloletnią tradycję i funkcjonuje stabilne ustawodawstwo sprzyjające rozwojowi energetyki odnawialnej. Członkowie spółdzielni są konsumującymi producentami i jednocześnie produkującymi konsumentami. Spółdzielnie można nazwać innym słowem: organizacją prosumentów. Dlatego bardziej niż wszystkie formy organizacyjne nadają się do zapewnienia dóbr życiowych i gospodarczych, które powstają $\mathrm{w}$ warunkach naturalnych monopoli. Dotyczy to energetyki jako usługi infrastrukturalnej (Maron, 2014).

Dynamiczny rozwój spółdzielni energetycznych w Niemczech następuje od 2008 roku, ze stałą tendencją wzrostowa. W 2014 roku najwięcej działało w sektorze fotowoltaicznym (69\%), trzykrotnie mniej w zakresie wytwarzania energii elektrycznej lub cieplnej z biomasy (21\%) a najmniej w wytwarzaniu energii z wiatru (8\%) i innych źródeł (2\%) (Debor, 2014). Średnia liczba członków spółdzielni wynosiła 160 osób (według niemieckiego prawa do założenia spółdzielni potrzebne są jedynie 3 osoby), z czego $91 \%$ były to osoby fizyczne, a tylko w $4 \%$ banki lub przedsiębiorstwa, w 3,5\% rolnicy, a w 1,5\% samorządy. Aby przystąpić do spółdzielni energetycznej potrzebne było średnio 714 euro na wykupienie pojedynczego udziału. Udziały te zależały od indywidualnych ustaleń i zaczynały się od 50 euro. Jednak średni wkład w zakładaną spółdzielnie wynosił aż 3172 euro. Początkowy kapitał przeciętnej niemieckiej spółdzielni energetycznej wynosił 800 tys. euro a na jedną spółdzielnie przypadały inwestycje o wartości 1,6 mln euro (Energy 
Transition, 2014). W wyniku zmian prawnych w 2012 roku rozwój niemieckich spółdzielni energetycznych trochę spowolnił. Przyczyną była redukcja taryf stałych i wprowadzenie systemu aukcyjnego.

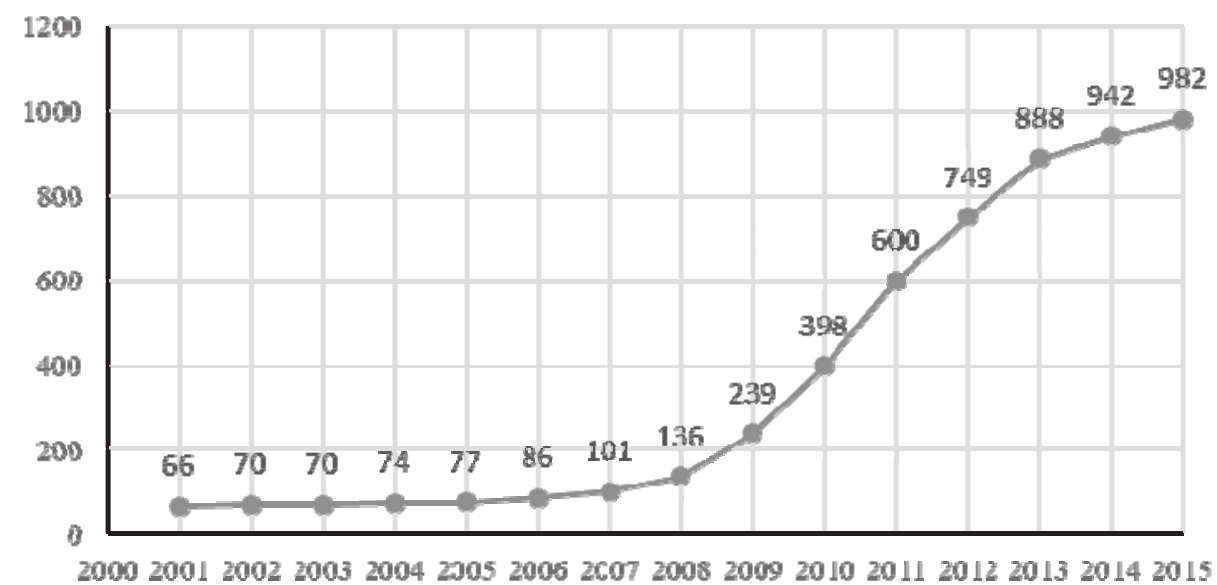

Rys 2. Liczba spółdzielni energetycznych w Niemczech w latach 2001-2015

Fig. 2. Quantity energy cooperatives in Germany from 2001-2015

Źródło: opracowanie na podstawie Debor 2014 oraz www.dgrv.de... 2016.

Ważnym powodem corocznego wzrostu liczby spółdzielni jest wysoki poziom świadomości ekologicznej, która wiąże się z potrzebą działania na rzecz dobra wspólnego jakim jest dobry stan środowiska naturalnego, w którym żyje człowiek. Odbywa to się bez specjalnych preferencji prawnych, gdyż zgodnie z niemieckim prawem spółdzielnie energetyczne traktowane są jak inne przedsiębiorstwa energetyczne (Energy cooperatives, 2012). Zgodnie z treścią opinii Europejskiego Komitetu Ekonomiczno-Społecznego (Opinia..., 2017) doświadczenia niemieckie ostatnich lat pokazują, że celem spółdzielni energetycznych nie jest maksymalizacja zysków ale przede wszystkim pomoc gospodarcza i wspieranie swoich członków. Z blisko tysiąca funkcjonujących podmiotów co czwarty finansował się jedynie z udziałów jej członków. W przypadku pozostałych 2/3 środków pozyskiwana była $\mathrm{z}$ banków spółdzielczych. Zaletą spółdzielni energetycznych był znikomy odsetek bankructw tej formy działalności (ok. 0,1\% wszystkich bankructw w Niemczech). Dzięki uruchomieniu aktywności obywateli powstają inicjatywy, które nie tylko poprawiają warunki życia, ale także wpływają na rozwój innowacyjnych technologii i tworzą trwałe miejsca pracy. Działalność spółdzielni energetycznych, m.in. dzięki pokrywaniu potrzeb energetycznych, a także generowaniu dodatkowych przychodów, jest ważnym instrumentem przeciwdziałania ubóstwu energetycznemu (Rehm, Karaczun, 2014).

Na podstawie badań przeprowadzonych przez Klaus Nowy Instytut (DGRV) w 2012 roku wśród 509 nowo utworzonych spółdzielni prowadzących przedsięwzięcia w zakresie energetyki podstawowym powodem oraz motywem założenia spółdzielni w Niemczech było wsparcie odnawialnych źródeł energii, które przekładało się na wzrost regionalny. 
Równie ważne było bezpieczeństwo energetyczne, samowystarczalność energetyczna i opłacalność produkcji energii. Cele te w znacznym stopniu można osiagnnąć wybierając spółdzielnie jako formę prawną inwestycji energetycznych w Niemczech. Forma ta jest preferowana dzięki możliwości demokratycznego podejmowania decyzji, realizację wspólnych potrzeb, samorządności i solidarności w osiaganiu wspólnych celów.

$\mathrm{Na}$ dalszy rozwój spółdzielni energetycznych w Niemczech wpłynie nowelizacja ustawy o odnawialnych źródłach energii (EEG) przyjęta 8 lipca 2014 r. w ramach tzw. "wielkiej koalicji” partii CDU/CSU i SPD. Nowe zasady wsparcia OZE w Niemczech w ramach systemu aukcyjnego przewidują wprowadzenie specjalnych warunków dla inwestorów prywatnych, spółdzielni energetycznych i innych projektów obywatelskich (Przyszłość energetyki, 2015). Najważniejsze zmiany polegają na tym, że lokalne projekty są zwolnione z konieczności przedłożenia niektórych rodzajów pozwoleń na etapie składania oferty, co ma na celu zmniejszenie ryzyka finansowego do minimum. Ponadto wielkość dofinansowania wynosi, inaczej niż w przypadku innych inwestorów, równowartość najdroższej oferty, jaka w ramach aukcji otrzymała wsparcie.

Najistotniejsze jest jednak to, że polityka energetyczna wyłączona jest ze sporów politycznych i jest kontynuowana niezależnie od wyników wyborów parlamentarnych.

\section{Spółdzielczość socjalna i energetyczna w Polsce}

Spółdzielnie socjalne w Polsce mają krótką historię, gdyż dopiero przyjęta w 2004 roku ustawa o promocji zatrudnienia i instytucjach rynku pracy (Dz.U. z 2004, Nr 99, poz. 1001 z późn.zm.) określiła możliwość ich powstawania a sprecyzowała zasady funkcjonowania uchwalona w 2006 roku ustawa o spółdzielniach socjalnych (Dz.U. z 2006, $\mathrm{Nr}$ 94, poz.651 z późn.zm.). Tworzone w ramach nowych priorytetów przedsiębiorstwa społeczne mogą być nowym i trwałym elementem polskiej gospodarki. Łączyłyby one cechy podmiotu gospodarki społecznej z ekonomicznym charakterem przedsięwzięcia. Działalność ta miałaby charakter:

- rynkowy - działalność ekonomiczna wobec innych podmiotów rynkowych i konsumentów,

- publiczny - działalność ekonomiczna prowadzona na zlecenie władz publicznych,

- $\quad$ społeczny - działalność o charakterze reintegracyjnym wobec własnych pracowników lub/oraz społeczności lokalnych (Gostomczyk, 2015).

Spółdzielnie socjalne powinny być pierwszym etapem tworzenia spółdzielni energetycznych, klastrów energii i docelowo energetyki obywatelskiej, umożliwiającej powstawanie autonomicznych regionów energetycznych. Angażując lokalne zasoby pracy w pozyskanie zasobów biomasy, w pierwszej kolejności należy pozyskiwać wszelkiego rodzaju zasoby pochodzące $\mathrm{z}$ prześwietleń pielęgnacyjnych drzew przydrożnych, w parkach, trawy z trawników, z których można wytwarzać zrębki i brykiety. Surowce te powinny być wykorzystane w lokalnych, gminnych budynkach komunalnych i publicznych, do ogrzewania mieszkań (obecnie 70\% wykorzystywanej energii wykorzystywanych jest w celach grzewczych). Docelowo pozyskanie biomasy można rozszerzyć o biomasę leśną, odpadową, co pozwoli maksymalnie ograniczyć import węgla ze Śląska do północnych regionów kraju. 
Na podstawie danych z rejestru REGON na dzień 31 grudnia 2017 r. w Polsce zarejestrowanych było 1,6 tys. spółdzielni socjalnych. Najwięcej ich powstało w latach 2013 i 2014, odpowiednio 307 i 365. Jednak spośród 1,4 tys. zarejestrowanych na koniec 2016 r. spółdzielni socjalnych niecałe $2 / 3$ prowadziło aktywną działalność ( 0,9 tys.).

Z raportu GUS (Informacja sygnalna GUS, 2018) wynika, że w 2016 roku najwięcej spółdzielni socjalnych prowadziło działalność gospodarczą $\mathrm{w}$ sekcjach z zakresu związanego z zakwaterowaniem i usługami gastronomicznymi (19\%), usługami administrowania (18\%), przetwórstwa przemysłowego (13\%), opieki zdrowotnej i pomocy społecznej (12\%) oraz budownictwa (9\%). Zgodnie z treścią „Monitoringu spółdzielni socjalnych" (2015) czynności związane z wytwarzaniem energii odnawialnej przez spółdzielnie socjalne w rejestrach REGON po raz pierwszy pojawiły się w 2014 roku i stanowiły tylko $0,2 \%$ wszystkich spółdzielni socjalnych w Polsce, co oznacza, że w tej dziedzinie działalność prowadziły tylko trzy jednostki. W 2018 roku funkcjonowało 12 spółdzielni socjalnych zajmujących się odnawialnymi źródłami energii - $30 \%$ z nich prowadziło sprzedaż i montaż kolektorów słonecznych, 20\% turbin wiatrowych i $20 \%$ instalacji fotowoltaicznych. Spółdzielnie socjalne: „Elektro-energa” ze Strzelna, „ABC” z Niechobrza, „Zielona Praca” z Krakowa i „Brawo” z Elblagga zajmują się pozyskiwaniem biomasy na potrzeby energetyczne oraz produkcją brykietu i peletu.

Zgodnie $\mathrm{z}$ obowiązującym prawem spółdzielnie energetyczną można stworzyć na podstawie regulacji Prawa spółdzielczego (Dz.U. z 1982, Nr 30, poz. 210 z późn.zm.). Nie ma ograniczeń, co do składu osobowego oraz minimalnego wkładu członkowskiego. Spółdzielnię może założyć co najmniej 10 osób fizycznych lub 3 osoby prawne. W przypadku spółdzielni socjalnych zgodnie z nowelizacją obowiązująca od 31.03 .2018 roku liczba założycieli nie może być mniejsza niż 3 , jeżeli założycielami są osoby fizyczne i 2 , jeżeli założycielami są osoby prawne. Pierwszą i jak dotychczas jedyną funkcjonująca spółdzielnią energetyczną w Polsce jest spółdzielnia „Nasza Energia”, która powstała w 2014 roku i została powołana z inicjatywy zamojskiej firmy Bio Power sp. z o.o. oraz czterech gmin powiatu zamojskiego. W Polsce idea tworzenia spółdzielni energetycznych napotyka pewien opór wynikający ze świadomości kształtowanej przez poziom zaufania i zaangażowanie obywateli wpływającego na strukturę własności (Bauwens, 2010). Z definicji spółdzielnie nie mogą przynosić zysków. W przypadku spółdzielni energetycznej, która sprzedając energię swoim członkom osiagnie zysk, otrzymaną nadwyżkę musi zwrócić członkom i nie podlega ona opodatkowaniu, co stanowi korzystny mechanizm wspierania OZE. Aktualnie w Polsce istnieje dla tego typu przedsiębiorstw korzystny klimat $\mathrm{w}$ ramach dofinansowania unijnego na lata 2014-2020. Wsparcie finansowe dla modelowo wyposażonych spółdzielni energetycznych zajmujących się pozyskiwaniem biomasy powinno być przeznaczone na zakup środków transportowych umożliwiających zbiór i gromadzenie biomasy, rębaków do jej rozdrobnienia oraz brykieciarek do lokalnego wykorzystania nadwyżek słomy (Gostomczyk, 2015). Spółdzielnie takie powinny ściśle współdziałać z władzami samorządowymi, zaopatrując w energię na ich zlecenie, zwłaszcza w zakresie energii cieplnej. Taki model charakteryzuje się wysoką efektywnością (niskie koszty energii), produkcja ma charakter lokalny, rozproszony oraz sprzyja osiaganiu samowystarczalności energetycznej gminy lub regionu. Obecnie główną barierą w rozwoju nowych rozwiązań organizacyjnych w sektorze energetycznym jest niska aktywność władz lokalnych i regionalnych, po części wynikająca z braku wiedzy oraz pozytywnych doświadczeń innych krajów. 
Doświadczenia państw zachodnich dowodza, że spółdzielnie energetyczne ewoluują i mogą przybrać wyższe formy stając się częścią energetyki obywatelskiej. Mogą stanowić formę przejściową od prosumenta do klastra energetycznego. Tworzą je wszelkie projekty, w których osoby prywatne i/lub lokalne przedsiębiorstwa pojedynczo lub wspólnie inwestuja własny kapitał w obszarze energetyki. Nie ograniczają się one tylko do pozyskania i przetworzenia biomasy, dotyczą wszelkich form odnawialnych źródeł energii tj. fotowoltaiki, energii wiatrowej, wodnej. Jest to również bardzo pożądana forma dla rozwoju biogazowni rolniczych. Wysokie koszty inwestycyjne dla tej formy OZE są trudne do podjęcia przez pojedynczych rolników. Łącząc zarówno kapitały, jak i surowce wytwarzane w kilku gospodarstwach można stworzyć wspólny projekt, dzieląc się również korzyściami w postaci dochodów i utylizacji uciążliwych odpadów. Każdy członek spółdzielni - inwestor staje się właścicielem cząstkowym budowanej inwestycji. Produkują one więcej energii, niż wynoszą potrzeby jej członków. Ich główna rola polega na tym, że umożliwiają one obywatelom, niedysponującym odpowiednio dużym kapitałem na udział w inwestycjach i rozwoju lokalnych odnawialnych źródeł energii. Działania spółdzielni energetycznych $\mathrm{w}$ ramach energetyki rozproszonej przynoszą korzyści finansowe pojedynczym członkom, przyczyniają się do poprawy lokalnego bezpieczeństwa energetycznego, sprzyjają lokalnemu rozwojowi gospodarczemu i ochronie środowiska (Jasiulewicz i in., 2015). W tym wymiarze spółdzielnie energetyczne powinny być ważnym elementem gospodarki niskoemisyjnej na szczeblu samorządowym.

\section{Klastry energetyczne w Polsce}

Idea klastrów energii wpisuje się w formułę rozwoju energetyki rozproszonej generowanej przez lokalne wytwarzanie i konsumowanie energii w pobliżu odbiorcy. Wskazane działania klastra to również promowanie i inicjowanie lokalnych przedsięwzięć z zakresu OZE, poprawa efektywności energetycznej w celu osiągnięcia samowystarczalności energetycznej gmin i powiatów, wprowadzanie energooszczędnych i wysokoefektywnych technologii, wsparcie produkcji energii elektrycznej i ciepła w skojarzeniu (kogeneracja), zagospodarowanie odpadów komunalnych i ich energetyczne przetworzenie. Aktywną rolę $\mathrm{w}$ tworzeniu klastrów powinny odgrywać jednostki samorządu terytorialnego dysponujące odpowiednim kapitałem intelektualnym i zasobem surowcowym. Koncepcja klastra powinna zawierać opis: poszczególnych jego komponentów, wzajemnych powiązań interesariuszy, możliwe struktury organizacyjne porozumień, miejsca i roli jednostki samorządu terytorialnego, roli i funkcji koordynatora klastra, relacji z regionalnym operatorem sieci dystrybucyjnej energii oraz warunków wprowadzenia inteligentnych sieci elektroenergetycznych. 2017):

Kryteria formalne pozwalające identyfikować klastry energetyczne to (Koncepcja,

1. wymóg posiadania umowy klastra energii,

2. cele klastra na poziomie indywidualnym, lokalnym, regionalnym i krajowym,

3. zakres funkcjonalny klastra energii,

4. sposób powołania koordynatora,

5. sposób uregulowania relacji klastra energii z odbiorcą energii,

6. poziom zaspokojenia potrzeb energetycznych członków klastra, 
7. udział energii z OZE, z kogeneracji lub energii odpadowej w zużyciu energii członków klastra,

8. wzrost wskaźnika niezawodności dostaw energii.

Rozwój spółdzielni energetycznych oraz klastrów energii wpisuje się w politykę zrównoważonego rozwoju poszczególnych krajów europejskich. W wielu krajach stały się one elementem zielonej ekonomii, rozwoju lokalnego i regionalnego oraz jedną ze ścieżek polityki ochrony środowiska. Polityka klastrowa wspólnoty europejskiej odbywa się poprzez upowszechnianie dobrych praktyk i rozwiązań organizacyjnych $\mathrm{w}$ ramach inicjatyw do których między innymi należą (Sobol, 2016):

- Europejska Koalicja Klastrów, jako główna platforma wymiany informacji pomiędzy władzami krajowymi i regionalnymi,

- Europejskie Obserwatorium Klastrów (ECO), utworzone w 2007 roku jako baza informacji o inicjatywach klastrowych na terenie Unii Europejskiej,

- Europejska Fundacja Doskonalenia Klastrów jako inicjatywa o charakterze edukacyjno-szkoleniowym,

- Platforma edukacji o klastrach.

Funkcjonujące w Polsce klastry mają różne struktury oraz sieci współpracy i powiązań. W wykazie klastrów w Polsce (według stanu na dzień 30.09.2015 roku) wymienionych było 134 jednostek, z których 16 (tab. 1) jako branża wpisano energetyka, ciepłownictwo, OZE.

Prowadzony przez Ministerstwo Energii rejestr wskazuje że w okresie dwóch ostatnich lat liczba klastrów energii znacząco wzrosła. Na dzień 31 lipca 2017 na liście Ministerstwa Energii zarejestrowanych było 60 klastrów energii i inicjatyw klastrowych w zakresie OZE. W porównaniu do stanu poprzedniego wiele $\mathrm{z}$ nich ma wybitnie lokalny charakter ograniczający się do obszaru jednej gminy. Lokalny charakter klastrów sugerują podane przykładowe ich nazwy: Człuchowski Klaster Energii, Miastecki Klaster Energii, Ostrowski Klaster Energii, Pilski Klaster Energii oraz Klaster Energetyczny Gmina Gubin. Powstające klastry energii adresowane są do szerokiego wachlarza interesariuszy, których potrzeby powiązane są $\mathrm{z}$ energią elektryczna, cieplna, w szczególności pochodzącą ze źródeł odnawialnych. Przyczyniają się one do poprawy lokalnego bezpieczeństwa energetycznego i stanu środowiska naturalnego. Przykładem takich działań jest Słupski Klaster Energetyczny.

Słupski Klaster Energetyczny stworzono na bazie oczyszczalni ścieków w Słupsku, której potencjał energetyczny frakcji organicznej w ściekach wyceniono na $5-10 \mathrm{MJ} / \mathrm{m}^{3}$ $=1,4-2,8 \mathrm{~kW} / \mathrm{m}^{3}$ a łączny potencjał bioenergii $335 \mathrm{GJ} / \mathrm{d}$. Na potencjał ten składają się:

- własne osady z oczyszczalni ścieków Słupsk (215 GJ),

- osady nieustabilizowane z innych oczyszczalni powiatu słupskiego (15 GJ),

- osady z separacji (30 GJ),

- bioodpady (15 GJ),

- odpady zieleni (25 GJ),

- skratki (25 GJ),

- inne zanieczyszczone mechanicznie bioodpady (10 GJ).

Odpady te poddawane są fermentacji suchej, mokrej, dezintegracji i hydrolizie w biorafinerii Słupsk, pozwalającej uzyskać biogaz o wartości 195 GJ oraz po kompostowaniu nawóz organiczny Biotop. Biogaz w układzie kogeneracyjnym CHP przetwarzany jest $\mathrm{w}$ energię elektryczną i cieplną wykorzystywaną do zasilania instalacji spółki, parku wodnego lub innych odbiorców całorocznych, ponieważ nadwyżka energii 
cieplnej wynosi 80-100 GJ. Istotą tego projektu jest korzystne oddziaływanie społeczne wyrażające się tańszą energia, niższymi taryfami oraz zbilansowaniem całego systemu. Głównymi beneficjentami korzyści będzie lokalne społeczeństwo a udziałowcami spółki komunalne, jednostki prywatne i publiczne oraz ośrodki akademickie realizujące programy $\mathrm{B}+\mathrm{R}$. Docelowo do klastra dołączone zostaną farmy wiatrowe i fotowoltaiczne, lokalne zakłady przetwórcze dostarczające odpady z procesu produkcyjnego oraz lokalne zakłady produkcyjne zainteresowane odbiorem tańszego ciepła i energii. Celem strategicznym klastra jest wykorzystanie potencjału osadów i odpadów zgodnie z ideą niskoemisyjnej, zasobooszczędnej, inteligentnej gospodarki cyrkulacyjnej w przyjaznym samorządzie. Pozostałe cele szczegółowe to (Słupski Klaster Energetyczny, 2017):

- poprawa ekonomiki wytwarzania energii z wykorzystaniem OZE,

- stworzenie inteligentnego systemu zarządzania i bilansowania energią z wykorzystaniem magazynów energii - smart grid,

- wykorzystanie potencjałów i naturalnych synergii współpracy,

- wypełnienie wymogów wynikających z efektywności energetycznej dla dużych zakładów.

Tabela 1. Wykaz klastrów energii w Polsce (według stanu na dzień 30.09.2015 roku)

Table 1. List of energy clusters in Poland (as of 30.09.2015)

\begin{tabular}{|c|c|c|c|}
\hline L.p. & Nazwa klastra & Nazwa koordynatora & Miejscowość \\
\hline 1. & $\begin{array}{l}\text { Wspólnota Wiedzy i Innowacji w } \\
\text { Zakresie Generacji i Użytkowania }\end{array}$ & Politechnika Wrocławska & Wrocław \\
\hline 2. & Klaster Ekoinnowacje & $\begin{array}{c}\text { Niemiecko-Polska Fundacja Nowa } \\
\text { Energia }\end{array}$ & Lublin \\
\hline 3. & Lubelski Klaster Ekoenergetyczny & Fundacja Rozwoju Lubelszczyzny & Lublin \\
\hline 4. & Bioenergia dla Regionu & $\begin{array}{l}\text { Centrum Badań i Innowacji Pro- } \\
\text { Akademia }\end{array}$ & $\begin{array}{l}\text { Konstantynów } \\
\text { Lódzki }\end{array}$ \\
\hline 5. & $\begin{array}{l}\text { Małopolsko-Podkarpacki Klaster Czystej } \\
\text { Energii }\end{array}$ & AGH Kraków & Kraków \\
\hline 6. & Dolina Czystej Energii & FITiOE & Warszawa \\
\hline 7. & $\begin{array}{l}\text { Mazowiecki Klaster Efektywności } \\
\text { Energetycznej i Odnawialnych Źródeł } \\
\text { Energii }\end{array}$ & Mazowiecka Agencja Energetyczna & Warszawa \\
\hline 8. & Podkarpacki Klaster Energii Odnawialnej & $\begin{array}{c}\text { Stowarzyszenie „Podkarpacka } \\
\text { Ekoenergetyka” }\end{array}$ & Rzeszów \\
\hline 9. & $\begin{array}{l}\text { Północno-Wschodni Klaster } \\
\text { Ekoenergetyczny }\end{array}$ & $\begin{array}{l}\text { Podlaska Fundacja Rozwoju } \\
\text { Regionalnego }\end{array}$ & Białystok \\
\hline 10. & Bałtycki Klaster Ekoenergetyczny & $\begin{array}{c}\text { Instytut Maszyn Przepływowych } \\
\text { PAN }\end{array}$ & Gdańsk \\
\hline 11. & Klaster Innowacyjne Strategie & Klaster Innowacyjne Strategie S.A. & Katowice \\
\hline 12. & $\begin{array}{l}\text { Klaster na Rzecz Rozwoju Rynku } \\
\text { Prosumenckiego }\end{array}$ & $\begin{array}{l}\text { Regionalna Izba Przemysłowo- } \\
\text { Handlowa }\end{array}$ & Gliwice \\
\hline 13. & $\begin{array}{l}\text { Polski Klaster Techniczno- } \\
\text { Technologiczny POWERARTH }\end{array}$ & IRGIA Sp. z o.o. & Katowice \\
\hline 14. & $\begin{array}{l}\text { Świętokrzysko-Podkarpacki Klaster } \\
\text { Energetyczny }\end{array}$ & $\begin{array}{l}\text { Świętokrzyskie Centrum Innowacji i } \\
\text { Transferu Technologii Sp. z o.o. }\end{array}$ & Kielce \\
\hline 15. & $\begin{array}{l}\text { Centrum Innowacji Fotowoltaicznych } \\
\text { (Dolina Fotowoltaiki) }\end{array}$ & EN2EN & Kobylniki \\
\hline 16. & Klaster Kotlarski & Stowarzyszenie Klaster Kotlarski & Pleszew \\
\hline
\end{tabular}

Źródło: opracowanie na podstawie: Wykaz..., 2015. 
Inicjatywa budowy klastra jest początkiem tworzenia lokalnego systemu energetycznego, zmierzającego docelowo do tworzenia autonomicznego, samo wystarczającego regionu energetycznego.

Przyszły rozwój klastrów energetycznych zależy od regulacji prawnych dotyczących dopuszczalnych form prawnych, zasad koncesjonowania ich działalności, trwałości organizowania dedykowanych aukcji dla instalacji zrzeszonych w ramach klastra, mechanizmu rozliczeń wytwórcy energii z jej odbiorca. W początkowym okresie rozwoju istotne są również preferencje finansowe w ramach pomocy publicznej dla energetyki obywatelskiej. Istniejące obecnie możliwości wsparcia klastrów funkcjonują w ramach Regionalnego Programu Operacyjnego (RPO), w zakresie odnawialnych źródeł, zgodnie z ustaloną linią demarkacyjną (czyli podziałem działań między RPO a POIiŚ) oraz poprzez Program Operacyjny Infrastruktura i Środowisko (POIiŚ 2014-2020) - Oś I Zmniejszenie emisyjności gospodarki. Formą dofinansowania projektów realizowanych w ramach porozumień klastrowych są pożyczki i dotacje uzyskiwane na realizacje następujących działań:

Działanie 1.1 Źródła OZE;

Działanie 1.2 Efektywność energetyczna przedsiębiorstw;

Działanie 1.3.1 Termomodernizacja budynków publicznych;

Działanie 1.3.2 Termomodernizacja budynków mieszkalnych;

Działanie 1.4 Sieci elektroenergetyczne;

Działanie 1.5 Sieci ciepłownicze;

Działanie 1.6 Źródła wysokosprawnej kogeneracji.

Podział środków będzie następował po spełnieniu określonych koniecznych warunków przy ubieganiu się o wsparcie z POIiŚ (2014-2020) przy wykorzystaniu metody punktowej.

Rosnące znaczenie energii, zwłaszcza tej pozyskiwanej w sposób przyjazny środowisku, powoduje, że poszukiwane są alternatywne formy organizacyjne łączące interesy wytwórców i środowisk lokalnych w powiązaniu z ochroną środowiska. Klastry oraz spółdzielnie energetyczne przyczyniają się do wzrostu aktywności społecznej poprzez angażowanie obywateli we wspólne przedsięwzięcia, których korzyści - zarówno dochody, jak i wpływy z podatków pozostają w obrębie gminy. Przyczyniają się one również do wzrostu sprawiedliwości społecznej ponieważ umożliwiają obywatelom aktywne uczestnictwo w osiagganiu samowystarczalności energetycznej.

\section{Podsumowanie}

Analizy doświadczeń polskich i niemieckich w zakresie rozwoju spółdzielni energetycznych wskazują na różnorodność modeli rozwojowych w zakresie wykorzystywanych struktur organizacyjnych. Członkostwo w tych organizacjach to zaangażowanie obywateli w inwestycjach nienastawionych wyłącznie na zysk, ale przedsięwzięcie lokalne oparte na osiagganiu długoterminowych korzyści dla regionu i jego mieszkańców. Dzisiejsze spółdzielnie energetyczne obejmują szerokie spektrum działań na wielu poziomach rozwoju od kilku rolników zbierających i suszących drewno do dużych projektów hybrydowych. Najprostszym modelem są spółdzielnie energetyczne funkcjonujące na zasadach spółdzielni socjalnych. Forma ta najbardziej polecana jest na obszarach wiejskich w zakresie pozyskiwania biomasy energetycznej dla lokalnych, najczęściej komunalnych ciepłowni. Na obszarach wiejskich funkcjonuje liczna grupa 
małych przedsiębiorstw komercyjnych zajmujących się produkcją drewna kominkowego, produkcją brykietów, sprzedażą zrębków pozyskiwanych w lasach i plantacjach dedykowanych. Działalność ta może być kompleksowo prowadzona przez spółdzielnie energetyczne. Przy właściwej organizacji byłyby one w stanie zagwarantować całoroczne zatrudnienie tej części ludności wiejskiej, która z powodu niskich kwalifikacji nie radzi sobie na rynku pracy. Dla zapewnienia ciagłości zatrudnienia i źródeł dochodów powinny one zajmować się pozyskaniem biomasy $\mathrm{w}$ ramach prac pielęgnacyjnych $\mathrm{w}$ przydrożnych zalesieniach i parkach komunalnych, zbioru trawy z terenów rekreacyjnych, komunalnych i jej sprzedaży jako surowca lokalnym biogazowniom. W sezonie zimowym podstawową działalnością powinno być wytwarzanie brykietów, peletów i konfekcjonowanego drewna kominkowego. Kolejną ścieżką rozwojową spółdzielni energetycznych powinna być lokalna konsolidacja prosumentów w grupy występujące jako jednolity podmiot w stosunku do znacznie silniejszego na rynku operatora odbioru energii. Ostatnią formą powinny być klastry energii o zasięgu regionalnym, które powinny zajmować się opracowywaniem i wdrażaniem planów rozwoju energetyki odnawialnej i niskoemisyjnej z wykorzystaniem innowacyjnych rozwiązań dla osiagania wysokiej efektywności ekonomicznej, energetycznej oraz jak najwyższych efektów ochrony środowiska.

$\mathrm{Na}$ podstawie przeprowadzonych analiz doświadczeń i działań podejmowanych w Polsce i Niemczech można stwierdzić, że czynnikami rozwoju spółdzielni energetycznych i klastrów są:

- stabilne i spójne ustawodawstwo,

- proste i przejrzyste procedury administracyjne,

- długoletnie taryfy gwarantowane, zawarte w umowach na sprzedaż wytworzonej energii, udziału,

- ograniczenie odpowiedzialności finansowej członków do wysokości wniesionego

- zapewnienie realnego wpływu członków spółdzielni na jej funkcjonowanie,

- wsparcie inwestycyjne,

- wysoka świadomość ekologiczna.

\section{Literatura}

Bauwens, T. (2010). What roles energy cooperatives in the diffusion of distributed generation technologies?, Centre for Social Economy, University of Liege.

Cooperative energy: lessons from Denmark and Sweden, Report of global watch mission, October 2004, The Union of cooperative enterprises.

Debor, S. (2014). The socio-economic power of renewable energy production cooperatives in Germany: Results of an empirical assessment, Wuppertal Papers, No. 187.

DGRV. Deutscher Genossenschafts - und Raiffeisenverband e.V., Energy cooperatives - results of the survey carried out in spring 2012, Berlin 2012.

Energy Transition, The German Energiewende, Moriis Craig, Pehnt Martin, Heinrich Boll Stiftung 2014.

Gostomczyk, W. (2015). Wykorzystanie biomasy energetycznej do kreowania rynku pracy - w aspekcie rozwoju zrównoważonego (The use of energy biomass to create the labor market - in the aspect of sustainable development). Wyd. Politechniki Koszalińskiej, Koszalin.

Gradziuk, P. (2017). Wykorzystanie energii ze źródeł odnawialnych a zatrudnienie (The use of energy from renewable sources and employment). Roczniki Naukowe SERIA, 19(6), 92-98.

Informacja sygnalna GUS: Spółdzielnie socjalne w 2016 r. (2018) (Information provided by the Central Statistical Office: Social cooperatives in 2016). Wyd. GUS, Warszawa. 
Jasiulewicz, M., Gostomczyk, W., Zarębski, P. (2015). Wykorzystanie biomasy rolniczej do celów energetycznych (The use of agricultural biomass for energy purposes). Wydawnictwo Instytutu Maszyn Przepływowych im. R. Szewalskiego PAN w Gdańsku.

Klaus Nowy Instytut; Genossenschaftliche Unterstzungsstrukturen fur eine sozialraumlich orientierte Energiewirschaft. (2014), Koln.

Koncepcja funkcjonowania klastrów energii w Polsce (The concept of functioning of energy clusters). (2017). KAPE, WiseEuropa, KIER na zlecenie Ministra Energii, Warszawa.

Maron, B. (2014). Spółdzielnie energetyczne w Niemczech (The energy cooperatives in Germany). W: Red. Z.M. Karaczun, Energetyka obywatelska w Polsce i w Niemczech: własne źródła, najmniejsze koszty, Wyd. SGGW, Warszawa, 145-157.

Monitoring spółdzielni socjalnych 2014, raport z badań (2015) (Monitoring of social cooperatives 2014, test report) Wyd. Ars Nova, Warszawa.

Odmienić przyszłość energetyki. Społeczeństwo obywatelskie jako główny podmiot produkcji energii ze źródeł odnawialnych. Analiza EKES-u na temat roli społeczeństwa obywatelskiego we wdrażaniu dyrektywy UE w sprawie odnawialnych źródeł energii (2015) (Change the future of energy. Civil society as the main subject of energy production from renewable sources. EESC analysis on the role civil society in implementing the EU directive on renewable energy sources). Pobrano z: ww.ieo.pl/dokumenty/aktualnosci/28012015/ 150122 RED Study polish version.pdf (2015).

Opinia Europejskiego Komitetū Ekonomiczno-Społecznego „Energetyka prosumencka i prosumenckie spółdzielnie energetyczne - możliwości i wyzwania w państwach członkowskich UE” (Opinion of the European Economic and Social Committee „Prosumer energy and prosumer energy cooperativesopportunities and challenges in EU Member States”). Dziennik Urzędowy UE 2017/ C 034/07.

Przyszłość energetyki odnawialnej w Niemczech - stały trend, nowe zasady (2015) (The future of renewable energy in Germany - a constant trend, new rules). Heinrich Boll Stiftung, Warszawa.

Raport Instytutu Badań Społecznych (Report of the Institute for Social Research). (2018) Warszawa.

Rehm, M., Karaczun, Z.M. (2014). Spółdzielnie energetyczne w Niemczech (Energy cooperatives in Germany). W: Red. Z.M. Karaczun, Energetyka obywatelska w Polsce i w Niemczech: własne źródła, najmniejsze koszty. Wyd. SGGW, Warszawa, 102-110.

Schumacher, E. (1981). Małe jest piękne (Smal is beautiful). PIW, Warszawa.

Słupski Klaster Energetyczny - idea projektu (Słupsk Energy Cluster - the idea of the project). Konferencja Ministerstwa Energii, Warszawa 30 czerwca 2017 r.

Sobol, A. (2016). Polityka rozwoju ekoklastrów w Polsce i Unii Europejskiej (The development Policy of ecoclassters in Poland and the European Union). Zeszyty Naukowe Uniwersytetu Ekonomicznego w Katowicach, 270, 243-251.

Tarhan, M.D. (2015). Renewable Energy Cooperatives: A Review of Demonstrated Impacts and Limitations, Journal of Enterpreneurial and Organizational Diversity, 4(1), 104-120.

Ustawa o odnawialnych źródłach energii (Act of 10 June 2016 amending the Renewable Energy Sources). Dz.U. z 2015, poz. 478 z późn.zm.

Ustawa o promocji zatrudnienia i instytucjach rynku pracy (Act on promotion of employment and labour market institutions of 2004). Dz.U. z 2004, Nr 99, poz. 1001 z późn.zm.

Ustawa o spółdzielniach socjalnych (Act on social cooperatives). Dz.U. z 2006, Nr 94, poz.651 z późn.zm.

Ustawa prawo energetyczne (Act of energy law). Dz.U. z 2005, Nr 62, poz.552 z późn.zm.

Ustawa prawo spółdzielcze (Act of cooperative law). Dz.U. z 1982, Nr 30, poz. 210 z późn.zm.

www.dgrv.de/webde.nsf/272e312c8017e736c1256e31005cedff/adb485d6ddf23ae3c12577c4004e7281/\$FILE/DG RV-Geschaeftsbericht_2016.pdf.

Wykaz klastrów w Polsce (List of clusters in Poland). (2015), Ministerstwo Energii, Warszawa.

\section{Do cytowania / For citation:}

Błażejowska M., Gostomczyk W. (2018). Warunki tworzenia i stan rozwoju spółdzielni i klastrów energetycznych w Polsce na tle doświadczeń niemieckich. Problemy Rolnictwa Światowego, 18(2), 20-32; DOI: 10.22630/PRS.2018.18.2.31

Błażejowska M., Gostomczyk W. (2018). Conditions for the Creation and State of Development of Cooperatives and Energy Clusters in Poland Compared with Germany (in Polish). Problems of World Agriculture, 18(2), 20-32; DOI: 10.22630/PRS.2018.18.2.31 